\title{
METODOLOGI FATWA MAJELIS ULAMA INDONESIA
}

\author{
Al Fakhri Zakirman
}

\begin{abstract}
Abstrak
Majelis Ulama Indonesia (MUI) adalah organisasi keagamaan yang bersifat independen dan aspiratif. Dalam khittah pengabdiannya salah satu peran MUI adalah pemberi fatwa (al-iftâ'). Fatwa adalah penjelasan tentang hukum Islam yang ditanyakan oleh mustafti (peminta fatwa). Dalam menghasilkan sebuah fatwa, MUI menggunakan metodologi yang ditempuh oleh jumhur (mayoritas) ulama. Menjadikan al-Quran, sunnah, ijma' dan qiyas sebagai dalil. Menjadikan pendapat mazhab (Abu Hanifah, Malik, Al-Syâfi'i dan Ahmad) sebagai patokan utama. Melakukan tarjih (memilih salah satu pendapat yang paling kuat) jika pada masalah tersebut ada beberapa pendapat. Apabila masalah yang dibahas belum pernah dibahas oleh ulama sebelumnya, maka MUI menggunakan metode takhrij (menganalogikan masalah yang belum dibahas dengan yang sudah pernah dibahas ulama klasik). Jika tidak memungkinkan takhrij, MUI melakukan ijtihad kolektif. Dalam pengambilan sebuah hukum MUI sangat mempertimbangkan aspek kekuatan dalil dan aspek kemaslahatan bagi umat.
\end{abstract}

Kata Kunci : fatwa, metodologi, MUI

\section{A. Pendahuluan}

Setiap produk figh yang dihasilkan oleh para pakar hukum Islam, pasti melewati proses ijtihad. Proses ijtihad berjalan dengan benar jika memiliki metodologi yang benar. Metodologi dalam hukum Islam adalah ushul fiqh, setiap produk fiqh pasti mempunyai dasar-dasar ushul fiqh.

IImu ushul fiqh pertama kali ditulis oleh Imam Al-Syâfi'i (204 H). Lalu ilmu ini berkembang ditandai dengan munculnya kitab-kitab ushul figh populer pada periode setelah Imam Al-Syâfi'i, seperti:
Al-Burhan karya Imam Al-Juwainî, AlMustashfâ karya Imam Al-Ghazalî, AlMahshûl karya Imam Al-Râzi, dan lainlain.

Dalam khazanah keilmuan Islam, menurut $M$. Atho Mudzhar dalam pengantarnya pada buku yang berjudul, "Problematika Hukum Keluarga Islam Kontemporer", ushul fiqh setidaknya memiliki empat produk hukum yaitu: fiqh, fatwa, qadlâ' (yurisprudensi) dan perundang-undangan (Zein, 2005 :XXVII). 
Fiqh adalah ilmu tentang hukum syara' (Baca: Islam) yang berkaitan dengan amalan nyata seorang hamba yang diambil dari dalil-dalil secara rinci (Al-Minyawi, 2011 :5). Sedangkan fatwa adalah memberi penjelasan tentang hukum syara' (Islam) pada suatu persoalan, sebagai bentuk jawaban bagi peminta fatwa, baik itu peminta fatwa teridentifikasi atau tidak, individu atau kelompok (Al-Qaradlâwi, 1988 :11). Adapun qadlâ' (yurisprudensi) adalah keterangan tentang hukum syara' (Islam) dengan ketentuan yang mesti diikuti (Ibn Qayyim, 1973 :36).

Fatwa memiliki dimensi yang cukup luas dalam kehidupan bermasyarakat, lebih luas dari qadlâ'. Hal ini disebabkan oleh karena fatwa, mencakup seluruh sendi kehidupan beragama. Sendi kehidupan agama yang dimaksud antara lain: masalah akidah, pokok-pokok agama, dan hukum-hukum fiqh (Al-Asyqar, 1976 :24).

Seorang ahli agama, seperti kiyai, ustadz atau lainnya, menjadi rujukan dalam setiap persoalan agama yang dihadapi oleh masyarakat. Oleh karena itu seorang mufti (pemberi fatwa) harus terkualifikasi dengan baik. AlMâliki mengutip pendapat Ibn alSam'ânî, mengatakan bahwa seorang mufti mestilah memiliki tiga syarat, yaitu: mampu berijtihad, adil (berintegritas) dan tidak menggampangkan persoalan. Menggampangkan persoalan terlihat pada dua kondisi: Pertama, menggampangkan pada proses ijtihad dengan hanya mencukupkan ijtihadnya dengan dalil-dalil prematur. Kedua, mencari hal-hal yang paling ringan dalam beragama atau biasa disebut dengan tatabbu' al-rukhash (Al-Mâliki, 1998 :1314).

Sedangkan Al-Syirâzî dalam kitab al-Luma' fi Ushûl al-Fiqh, menyebutkan bahwa seorang mufti harus mengetahui sumber hukum Islam yaitu Al-Quran, secara khusus yang berkaitan dengan ayat-ayat hukum, halal dan haram. Begitu juga ia mesti mengetahui sunnah Nabi SAW, terkhusus yang berkaitan dengan hadits-hadits hukum. Selain itu, ia juga harus memahami hal-hal yang berkaitan dengan pemahaman nashnash Al-Quran dan Sunnah seperti: alhaqîqah dan al-majâz, al-âam dan alkhâsh, al-mujmal dan al-mufashhal, almuthlaq dan al-muqayyad, al-manthûq dan al-mafhûm, pemahaman bahasa, ilmu nahwu, hal-hal yang berkaitan dengan perbuatan Nabi, al-nâsikh dan al-mansûkh, ijmâ' ulama, memahami qiyas dan cara menggunakannya, mengetahui urutan dalil serta cara menentukan dalil yang paling kuat. Seorang mufti harus mempunyai integritas, dapat dipercaya dan tidak 
menggampang-gampangkan

urusan agama (Al-Syirâzî, 1995 :254-255). Imam Al-Syâthibî menambahkan syarat "moderat", bagi seorang mufti dalam memberi fatwa kepada masyarakat. Tidak membebani mereka dengan fatwa yang ekstrim dan juga tidak menjerumuskan mereka pada fatwa yang liberal (Al-Syâthibî, 2003 :276).

Penjelasan para pakar ushul fiqh di atas memberi kesimpulan bahwa seorang mufti mesti memiliki kapasitas keilmuan hukum Islam yang mumpuni, memiliki integritas moral yang baik. Di samping itu juga seorang mufti mesti mengetahui secara utuh kondisi mustafti (peminta fatwa), sehingga fatwa yang ia berikan moderat dan tepat.

Di Indonesia, peran iftâ' (pemberi fatwa) banyak diperankan oleh Majelis Ulama Indonesia. MUI adalah organisasi keagamaan yang bersifat independen, tidak berafiliasi kepada salah satu partai politik, mazhab atau aliran keagamaan Islam yang ada di Indonesia. (Azra, 2000 :65). Dalam khittah pengabdiannya, MUI memiliki lima fungsi dan peran utama, yaitu: 1) Sebagai pewaris tugas-tugas para Nabi; 2) Sebagai pemberi fatwa; 3) Sebagai pembimbing dan pelayan umat; 4) Sebagai perbaikan (islâh) dan pembaharuan (al-tajdîd), dan 5) Sebagai penegak amar ma'ruf dan nahi munkar (Mudzhar, 1993 :63).
Di beberapa negara-negara Arab, Seperti: Mesir, Jordania, Libanon, Palestina, Arab Saudi, fungsi iftâ' (pemberi fatwa) diperankan oleh lembaga fatwa negara yang diketuai oleh seorang mufti agung. Seorang mufti agung, haruslah memenuhi syarat-syarat yang ditentukan. Mesir misalnya, penentuan seorang mufti dilakukan secara demokratis oleh para ulama senior dari Universitas Al-Azhar, Kairo. Presiden hanya menyetujui hasil keputusan tersebut.

Sedangkan di Indonesia MUI tidak terlembaga di bawah pemerintah. Sehingga Lebih independen dan aspiratif. MUI berposisi sebagai mitra stategis pemerintah yang saling memberikan manfaat. Hal ini diungkapkan oleh mantan Ketua Umum MUI Prof. Dr. Din Syamsudin di acara pembukaan Munas IX MUI di Surabaya. "Simbiosis mutualisme antara pemerintah dengan ummat Islam (MUI) tampak dari kebijakan Presiden Susilo Bambang Yudhoyono (SBY) di hari terakhirnya menjabat presiden, 24 Oktober 2014, yang menetapkan anggaran $\mathrm{MUI}$ pusat berasal dari Anggaran Pendapatan dan Belanja Negara (APBN) dan MUI daerah dari APB Daerah (APBD) provinsi/ kabupaten," Lalu ia menegaskan: "Yakinlah bahwa umat Islam di Indonesia 
akan mendukung kebijakan pemerintah selama kebijakan itu berlandaskan pada nilai-nilai keagamaan, khususnya Islam" (www.dmi.or.id).

Belakangan fatwa MUI kembali terdengar nyaring. Beberapa fatwanya menjadi sorotan publik, seperti: sikap keagamaan MUI terkait pernyataan Gubernur DKI tentang Al Maidah 51, fatwa perihal shalat jumat di tempat selain di masjid. Terakhir, fatwa tentang penggunaan atribut keagamaan nonmuslim oleh muslim/muslimah.

Tulisan singkat ini mencoba menjelaskan tentang pengertian fatwa dan metodologi yang digunakan oleh MUI dalam menghasilkan fatwafatwanya.

\section{B. Antara Fatwa, Qadlâ' dan ljtihad}

Kata fatwa dalam bahasa Arab biasa disebut juga dengan al-futyâ atau al-fatwâ. Sedangkan memberi fatwa digunakan kata al-ifta' yang merupakan bentuk masdar dari kata kerja aftâ-yuftî artinya menjelaskan dan menerangkan. Contoh: aftâ al-âlim orang alim itu memberi penjelasan (Ibn Manzhûr, 1414 H :147). Sedangkan kata al-futyâ adalah bentuk lain dari kata al-fatwâ dua kata yang memiliki makna sama. Râghib alAsfahâni menyebutkan bahwa kata alfutyâ dan al-fatwâ adalah jawaban terhadap persoalan-persoalan hukum (Al-Asfahâni, 1412 H :625).

Bisa disimpulkan bahwa fatwa adalah jawaban dari pertanyaanpertanyaan yang ditujukan kepada seorang mufti (pemberi fatwa) oleh mustafti (peminta fatwa). Sedangkan aliftâ' adalah proses memberikan penjelasan fatwa oleh seorang mufti.

Defenisi fatwa menurut para pakar ushul fiqh tidak jauh berbeda dengan pengertian fatwa menurut ahli bahasa. Al-Qarâfi mendefinisikan fatwa dengan memberi keterangan tentang hukum Allah Swt, baik yang bersifat mulzim (wajib diikuti) atau tidak. (AlQarâfi, 1994 :121). Sedangkan Ibnu Hamdan menyebutkan bahwa fatwa adalah menyampaikan penjelasan tentang hukum syara' (Islam) berdasarkan dalil syar'i. (Ibn Hamdan, $1397 \mathrm{H}: 4)$.

Syeikh AI-Qaradlâwi memperjelas defenisi fatwa dengan menambahkan unsur mustafti (peminta fatwa). Fatwa adalah memberi penjelasan tentang hukum syara' (Islam) pada suatu persoalan sebagai bentuk jawaban bagi peminta fatwa baik itu peminta fatwa teridentifikasi atau tidak, baik itu individu atau kelompok. (Al-Qaradlâwi, 1988 :11).

Dapat disimpulkan bahwa fatwa adalah memberi penjelasan tentang hukum syara' (Islam) berdasarkan al- 
Quran, sunnah, ijmâ', qiyâs atau dalildalil syar'i yang lain untuk menjawab pertanyaan mustafti (peminta fatwa). Terlepas apakah peminta fatwa adalah individu, kelompok atau lembaga. Fatwa juga tidak mempunyai kekuatan yang mengikat kepada mustafti.

Adapun Qadlâ' terambil dari bahasa Arab. Bentuk masdar dari qadlayaqdli berarti menetapkan, menyelesaikan, melaksanakan, menciptakan dan kematian. Sedangkan qadlâ' menurut pakar ushul fiqh adalah menyampaikan hukum syara' (Islam) dengan ketentuan harus diikuti (Ibn Qayyim, $1973: 36$ ).

Defenisi ini masih umum karena tidak menyoroti kewenangan yang dimiliki oleh seorang qâdli, hanya menyebutkan kewajiban seorang yang diputus perkara. Ibn Khaldun menyebutkan defenisi yang lebih jelas tentang qadlâ' (yurisprudensi). Qadlâ' adalah jabatan yang bertujuan untuk memutuskan segala bentuk persengketaan di masyarakat, mencegah segala bentuk dakwaan, memutus segala bentuk perselisihan. (Ibn Khaldun, 1984 :173).

Defenisi ini lebih tegas menyebutkan tentang wewenang dan posisi seorang qâdlî. Qadlâ' (yurisprudensi) dan fatwa memiliki persamaan. Di antaranya adalah qadla' dan fatwa sama-sama memberikan penjelasan tentang hukum syara' (Islam). Di samping itu hukum yang dilahirkan oleh qadlâ' dan fatwa sama-sama memiliki dasar-dasar ushul figh.

Namun keduanya juga memiliki banyak perbedaan.di antaranya: Pertama, Fatwa adalah penjelasan tentang hukum syara' (Islam) tanpa mengikat mustafti secara hukum. Sedangkan seorang yang diputus perkaranya terikat oleh keputusan yang diambil oleh qâdli. Kedua, Qadlâ' (Yurisprudensi) tidak bisa dibatalkan oleh fatwa, sedangkan fatwa bisa dibatalkan baik oleh fatwa yang lain atau oleh putusan peradilan. Ketiga, Qadlâ' (Yurisprudensi) disampaikan secara lisan atau tertulis, sedangkan fatwa bisa berbentuk lisan, tulisan, perbuatan atau isyarat. Keempat, Seorang qâdli terikat pada argumentasi, keterangan dan buktibukti yang dihadirkan kepadanya, sedangkan seorang mufti boleh memberi fatwa tanpa memiliki bukti-bukti di hadapannya (Ibrahim, 2007 :46-49).

Fatwa juga memiliki kemiripan dengan ijtihad. Karena berfatwa sama dengan berijtihad. ljtihad adalah mengeluarkan semua kemampuan untuk mendapatkan hukum syara' (Islam) yang berhubungan dengan perbuatan mukallaf dengan cara istinbath (Melahirkan 
hukum dengan dalil) (Al-Syaukani, 1999 :205).

Sebagian pakar ushul fiqh seperti: al-Syaukâni, Ibn Rusyd, Rasyid Ridhâ, Wahbah Zuhaili beranggapan bahwa tidak ada perbedaan antara fatwa dan ijtihad, karena seorang mufti pasti seorang mujtahid. Namun jika dilihat lebih jauh, fatwa dan ijtihad berbeda. Fatwa lebih khusus dari ijtihad. Berikut perbedaan fatwa dan ijtihad:

Pertama, Objek ijtihad adalah hukum syara' (Islam) yang bersifat zhanni (tidak pasti), sedangkan fatwa objeknya lebih umum, sesuai dengan kebutuhan mustafti (peminta fatwa). Kedua, Seorang mujtahid ketika melakukan istinbâth (mencari sebuah hukum) tidak memperhatikan kondisi individu per individu, hanya fokus pada masalah. Sedangkan seorang mufti ketika mengeluarkan fatwa mesti memperhatikan hal-hal yang meliputi masalah dan kondisi mustafti (peminta fatwa). Ketiga, Fatwa biasanya berawal dari pertanyaan masalah yang dialami oleh mustafti sedangkan ijtihad bersifat lebih umum, baik masalah yang telah terjadi ataupun belum (Ibrahim, 2007 :63-65).

\section{Fatwa dan Sikap Keagamaan Majelis Ulama Indonesia}

Majelis Ulama Indonesia adalah wadah yang dibentuk untuk menghimpun para ulama, zuama dan cendekiawan muslim Indonesia guna menyatukan gerak dan langkah-langkah umat Islam Indonesia dalam mewujudkan cita-cita bersama. Majelis Ulama Indonesia berdiri pada tanggal 7 Rajab $1395 \mathrm{H}$ bertepatan dengan tanggal 26 Juli 1975 di Jakarta, lahir dari hasil pertemuan musyawarah ulama se-Indonesia. (Sekretariat MUI, 1995 :13).

Dalam khittah pengabdiannya salah satu fungsi dari Majelis Ulama Indonesia adalah sebagai pemberi fatwa (al-iftâ) kepada umat Islam atau pemerintah, baik diminta maupun tidak diminta. Berdasarkan informasi yang dirilis oleh website resmi MUI, setidaknya ada 4 jenis fatwa yang dikeluarkan oleh MUI:

1. Fatwa Komisi Fatwa MUI.

Adalah fatwa yang dikeluarkan oleh komisi fatwa MUI setelah melakukan pengkajian terhadap suatu permasalahan. Beberapa fatwa paling anyar yang dihasilkan oleh komisi fatwa adalah hukum menggunakan atribut non muslim, fatwa perihal shalat jumat di tempat selain mesjid, dan lain-lain.

Sebelum membahas sebuah masakah, komisi fatwa terlebih dahulu mendengarkan dan mempertimbangkan pendapat para ahli dalam bidang yang berkaitan dengan masalah tersebut, Sehingga fatwa yang dihasilkan tepat. 
2. Fatwa Dewan Syari'ah Nasional MUI

Dewan Syariah Nasional MUI dibentuk dalam rangka mewujudkan aspirasi umat Islam mengenai masalah perekonomian. Mendorong penerapan ajaran Islam dalam bidang perekonomian dan keuangan yang dilaksanakan sesuai dengan tuntunan syariat Islam.

Di antara tugas yang diamanahkan kepada Dewan Syariah Nasional adalah mengeluarkan fatwa tentang ekonomi syariah untuk dijadikan pedoman bagi regulator dan praktisi. Beberapa fatwa yang dihasilkan oleh Dewan Syariah Nasional MUI adalah wakaf manfaat asuransi dan manfaat investasi pada Asuransi Jiwa Syariah, sertifikat deposito syariah dan lain-lain.

\section{Fatwa Hasil Munas MUI}

Musyawarah Nasional MUI adalah forum nasional lima tahunan MUI, dan fatwa hasil Munas MUI adalah fatwa yang dikeluarkan oleh MUI ketika pelaksanaan Munas. Pada pelaksanaan Munas terakhir di Surabaya tahun 2015, beberapa fatwa yang dihasilkan antara lain: fatwa kriminalisasi hubungan suami isteri dan fatwa tentang pendayagunaan harta zakat, infaq, sedekah dan wakaf untuk pembangunan sarana air bersih dan sanitasi.

\section{Fatwa ljtima' Ulama}

Fatwa ijtima' ulama adalah hasil pertemuan seluruh komisi fatwa seIndonesia untuk membahasa masalahmasalah strategis kebangsaan dan keummatan. Hasil ijtima' terakhir dilaksanakan pada tahun 2015 di Tegal Jawa Tengah. Di antara keputusan fatwa yang dihasilkan adalah tentang kedudukan pemimpin yang tidak menepati janji, kriteria pengkafiran, radikalisme agama, pemanfaatan tanah untuk kesejahteraan umat dan bangsa, penyerapan hukum Islam ke dalam hukum nasional.

Fatwa ijtima' ulama ini memiliki posisi yang lebih kuat karena ini merupakan hasil pembahasan yang dilakukan oleh ulama se-Indonesia, bisa disebut hasil ini dengan ijma' lokal.

Adapun Sikap Keagamaan MUI menurut Wakil Ketua Umum MUI M Zainut Tauhid memiliki kedudukan yang lebih tinggi dari fatwa yang dihasilkan oleh komisi fatwa, karena fatwa hasil komisi fatwa dibuat dan ditandatangani oleh ketua dan sekretaris komisi fatwa. Sedangkan, sikap keagamaan tersebut dibahas di rapat pimpinan MUI dan ditandatangani oleh Ketua Umum dan Sekretaris Jenderal. Sikap Keagamaan yang pernah dikeluarkan oleh MUI adalah sikap terkait "Pernyataan Basuki 
Tjahaya Purnama" pada tanggal 11 Oktober 2016. (www.republika.co.id).

\section{Metodologi Fatwa Majelis Ulama Indonesia}

Secara umum MUI sudah menyusun Pedoman Penetapan Fatwa Majelis Ulama Indonesia Nomor: U596/MUI/X/1997. Dalam pedoman tersebut disebutkan bahwa setiap fatwa harus berupa pendapat hukum yang mempunyai dasar-dasar paling kuat dan membawa maslahat bagi umat. Dasardasar yang dijadikan pegangan dalam melahirkan fatwa adalah al-Quran, hadits, ijma', qiyas dan dalil-dalil hukum lainnya.

\section{Dasar pijakan MUI dalam} menghasilkan sebuah fatwa di atas adalah ijmâ' ulama. Imam Al-Syâfi'i dalam kitab Al-Risalah menyebutkan, "Tidak boleh seorang pun sampai kapan pun berbicara tentang apapun yang berkaitan dengan halal dan haram melainkan harus memiliki dasar ilmiah. Dasar ilmiah sebuah masalah adalah alQuran, sunnah, ijmâ' dan qiyas" (AlSyâfi'i, 1940 :37). Ibn Qayyim menyebutkan bahwa keempat dalil ini sudah disepakati dan tidak ada perbedaan disana, karena keempatnya saling mendukung dan saling membenarkan. (Ibn Qayyim, 1973 :33).

MUI dalam fatwanya juga tidak menolak dalil-dalil hukum selain yang disepakati para Ulama, seperti: istihsan, istishab, sad al-dzari'ah dan dalil-dalil lain yang masih diperdebatkan oleh para ulama.

Lebih lanjut MUI dalam membahas masalah terlebih dahulu memperhatikan dan mempertimbangkan pendapat para imam mazhab dan fuqaha terdahulu. Mencari tahu dasar-dasar dan bentuk istidlal-nya, dan mempertimbangkan yang paling maslahat bagi umat.

Jika masalah tersebut hanya terdapat satu pendapat saja, maka MUI (dalam hal ini komisi fatwa atau tim khusus) dapat mengambilnya sebagai keputusan fatwa. Hukum yang sudah disepakati melalui ijmâ' ini menjadi wajib untuk diikuti. Jika umat Islam menyepakati satu hukum, tidak boleh seorang pun yang keluar dari pendapat tersebut (Ibn Taimiyah, $1407 \mathrm{H}$ : 10).

Para ulama yang sudah menyepakati sebuah hukum melalui ijmâ', tidak diperkenankan untuk keluar dari yang sudah ia sepakati. (Ibn Najjâr, 1980 :249). Begitu juga bagi generasi berikutnya tidak boleh keluar dari yang sudah disepakati oleh para Ulama sebelum mereka pada masalah yang sama. (Al-Syâfi'i, 1940 :472).

Namun jika ternyata lebih dari satu pendapat, MUI melakukan pemilihan pendapat melalui tarjih 
(menguatkan satu pendapat). Pendapat yang memiliki dasar paling kuat dan maslahat paling besar untuk ummat akan dipilih sebagai keputusan fatwa. Tarjih adalah menetapkan sesuatu lebih kuat dari yang lain, Al-Râzi dalam kitab alMahshûl menyebutkan bahwa tarjih adalah memperkuat salah satu pendapat yang ada setelah mengetahui mana yang memiliki dasar paling kuat, lalu menggunakannya dan mengabaikan pendapat yang lemah. (Al-Râzi, 1400 H :397).

Tarjih merupakan sebuah keniscayaan karena tidak semua hukum syariat ditetapkan dengan dalil qath'î (pasti). Banyak dalil-dalil yang ada pada syariat memiliki dalil zhanni (tidak pasti), baik secara pemahaman teksnya maupun proses periwayatannya. Oleh karena itu muncul banyak pendapat dalam memahami satu masalah. Ketika ada perbedaan pendapat, seorang mujtahid perlu menentukan satu dari banyak pendapat yang akan digunakan dalam beramal. Memilih pendapat yang paling kuat ini lah yang biasa disebut dengan tarjih.

Beramal dengan dalil yang paling kuat menurut sebagian besar ulama hukumnya wajib. Sebaliknya, tidak boleh beramal dengan dalil dan dasar hukum yang lemah. (Al-Aâmidî, 1387 H :257).
Di antara dasar yang digunakan oleh pendapat pertama adalah ijmâ' Sahabat. Mereka berpendapat bahwa sahabat Nabi sepakat untuk beramal dengan dalil yang lebih kuat. Hal ini tampak di beberapa riwayat yang bertentangan. Seperti perkara mandi junub. Ada dua riwayat yang bertentangan dalam masalah ini. Riwayat pertama adalah riwayat Aisyah Ra. Riwayat kedua adalah riwayat Abu Hurairah Ra.

Pada riwayat Aisyah $\mathrm{Ra}$, disebutkan bahwa mandi junub wajib bagi suami istri setelah berhubungan badan. Baik itu inzâl (keluar mani) atau tidak. Sedangkan pada riwayat Abu Hurairah $\mathrm{Ra}$ mandi diwajibkan ketika inzâl saja.

Para sahabat mentarjih riwayat Aisyah $\mathrm{Ra}$, karena dianggap lebih mengetahui tentang rumah tangga Rasul. Jika tarjih dan beramal dengan dalil yang paling kuat tidak diperlukan, pasti para sahabat tidak melakukan tarjih terhadap riwayat-riwayat tersebut. (AlHifnâwi, 1987 :291).

Sebagian yang lain berpendapat bahwa jika ada dua dalil yang bertentangan, seorang mujtahid tidak perlu men-tarjih salah satu dari keduanya. Pilihannya hanya dua. Pertama: memilih salah satu tanpa melihat mana yang paling kuat. Kedua: 
tidak melanjutkan proses ijtihadnya. (AlIsnâwi :156).

Dalil yang mereka gunakan adalah al-Hasyr ayat 2. Artinya: "Maka ambillah pelajaran wahai orang-orang yang berakal". Ayat tersebut adalah perintah untuk berpikir dan mengambil pelajaran. Tanpa ada pembedaan terhadap dalil yang kuat atau yang lemah.

Al-Aâmidi menjawab bahwa kesimpulan yang diambil dari ayat tersebut tidak bertentangan dengan perintah untuk memakai dalil yang lebih kuat. Karena ayat tersebut perintah untuk berpikir secara umum. (Al-Aâmidi, $1387 \mathrm{H}$ :257).

Dalam melakukan tarjih seorang mujtahid perlu memperhatikan ramburambu umum tarjih. Adapun ramburambu yang perlu diperhatikan sebagai berikut:

1. Tarjih tidak diperkenankan pada dalildalil yang qath'i (pasti). Dalil qath'i tidak akan melahirkan perbedaan pendapat. Jika tidak ada perbedaan pendapat maka tidak ada tarjih.

Al-'Abbâdi menyebutkan "dua dalil yang qath'i (pasti), baik dalil akal ataupun naqli tidak akan bertentangan. Jika bertentangan mesti salah satu dari keduanya menasakh (membatalkan) dalil yang lain. (Al-'Abbâdi, 1356 H :148).
Begitu juga jika salah satu dari dalil tersebut zhanni (tidak pasti) dan yang kedua qath'i (pasti) dalam kondisi seperti ini secara otomatis dalil yang qath'i lebih didahulukan dibanding dalil yang zhanni.

2. Tarjih dilakukan jika tidak memungkinkan untuk mengkompromikan dua dalil yang bertentangan. Karena dengan mengkompromikan berarti mengamalkan dua dalil yang ada. Mengamalkan dua dalil jauh lebih baik dari pada mengamalkan satu dalil dan mengabaikan dalil yang lain.

Tetapi menurut ulama hanafi bahwa tarjih lebih baik dari pada mengkompromikan dua dalil. (Madkûr, $1395 \mathrm{H}: 321)$.

3. Tarjih bisa menggunakan dalil yang paling banyak. Artinya semakin banyak dalil dari satu pendapat akan semakin kuat pendapatnya.

Bila ada dua dalil yang bertentangan, sama-sama kuat, lalu ditemukan dalil ketiga yang menguatkan salah satu dari dua dalil tersebut maka dalil baru ini dianggap tarjih. (Al-Isnâwi :164).

Selanjutnya jika dalam pembahasannya MUI tidak menemukan pendapat terdahulu dari para ulama, berarti tidak ada tarjih. MUI melakukan metode ilhaq al-masail bi nazha'iriha 
(menganalogikan dengan masalah yang serupa) jika memungkinkan. Metode ini dilakukan dengan memperhatikan mulhaq bih (masalah yang belum dibahas ulama), mulhaq 'alaih (masalah yang sudah dibahas ulama) dan wajh alilhaq-nya (bentuk persamaannya).

Metode ini lebih dikenal dengan istilah takhrij. Secara sederhana takhrij adalah menganalogikan masalah yang tidak pernah dibahas oleh para ulama dengan masalah yang sudah pernah dibahas oleh para ulama. Istilah takhrij lebih populer digunakan oleh para pengkaji hadits, sedangkan dalam kajian-kajian fiqih-ushul fiqih terminologi takhrij belum banyak dipahami oleh sebagian sarjana muslim apalagi masyarakat awam.

Takhrij menurut pengkaji ushul fiqih terbagi menjadi tiga macam:

1. Takhrij al-ushûl min al-furû' adalah menemukan dasar-dasar hukum Islam yang digunakan oleh imamimam fiqih dengan cara mengumpulkan dan mengkaji produk hukum fiqih mereka. (Al-Bahsain, $1414 \mathrm{H}: 19)$.

Takhrij jenis ini biasa digunakan oleh pengikut mazhab Abu Hanifah untuk mengetahui dasar-dasar yang digunakan Imam Abu Hanifah dalam menetapkan sebuah hukum. Hal ini disebabkan karena Abu Hanifah semasa hidup tidak mewariskan dasar-dasar pengambilan hukum kepada murid-muridnya. Sehingga para penerus mencari sendiri dasar yang digunakan oleh Abu Hanifah melalui produk hukum fiqih yang beliau hasilkan.

2. Takhrij al-furû' 'ala al-ushûl menurut pengkaji ushul fiqih adalah ilmu yang membahas tentang illat (alasan dasar) atau sumber-sumber hukum syar'i yang dijadikan sebagai rujukan hukum-hukum furû' (cabang) untuk menjelaskan sebab-sebab perbedaan ulama, atau menjelaskan hukum yang tidak terdapat pada literatur-literatur imam mazhab baik pada kaedahkaedah fiqih atau ushul fiqih mereka. (Al-Bahsain, $1414 \mathrm{H}$ :51).

3. Takhrij al-furû' 'ala al-furû' menurut pengkaji ushul fiqih adalah memindahkan hukum sebuah masalah kepada masalah lain yang serupa. (Taimiyah, 2001 :948).

Takhrij model ini sering digunakan oleh ulama kontemporer dalam mencari hukum dari sebuah masalah, biasanya dengan menganalogikan masalah yang baru kepada masalah yang lama yang sudah diteliti oleh para ulama klasik, lalu mengambil hukumnya dan menerapkan hukum tersebut kepada masalah yang baru. 
Takhrij yang dilakukan oleh MUI adalah bentuk takhrij ketiga yaitu takhrij al-furû' ala al-furû'. Metode ini berpatokan pada pendapat yang pernah dibahas oleh para ulama terdahulu. Metode ini dilakukan dengan memperhatikan mulhaq bih, mulhaq 'alaih dan wajh al-ilhâq-nya. Jika takhrij juga tidak dapat dilakukan, maka MUI (dalam hal ini komisi fatwa) melakukan ijtihad jamâ'i (pendapat kolektif) dengan menggunakan kaidah-kaidah ushul figh dan fiqh.

Jika kita telaah lebih jauh, penetapan fatwa MUI mempertimbangkan maslahat umat Islam. Pada Munas MUI tahun 2005 ditetapkan keputusan tentang kriteria maslahat. Menurut Imam Al-Ghazâli, maslahat makna asalnya berarti menarik manfaat atau menolak mudarat (hal-hal yang merugikan). Akan tetapi, bukan itu yang kami maksud, sebab meraih manfaat dan menghindarkan mudarat adalah tujuan makhluk (manusia). Kemaslahatan makhluk terletak pada tercapainya tujuan mereka.

Maslahat yang kami maksud adalah memelihara tujuan syara' (hukum Islam). Tujuan syara' yang ingin dicapai dari makhluk ada lima: yaitu memelihara agama, jiwa, akal, keturunan, dan harta mereka. Setiap hukum yang mengandung tujuan memelihara kelima hal ini disebut maslahat; dan setiap hal yang meniadakannya disebut mafsadat dan menolak mafsadat disebut maslahat (Al-Ghazâli, 1993 :175).

Sedangkan Al-Syâthibi dalam alMuwâfaqât menyebutkan bahwa setiap dasar agama yang tidak ditunjuk oleh nash tertentu dan ia sejalan dengan tindakan syara' serta maknanya diambil dari dalil-dalil syara', maka hal itu benar, dan dapat dijadikan landasan hukum dan rujukan, demikian itu apabila kemaslahatan tersebut dapat dipastikan kebenarannya. Sebab dalil-dalil tidak mesti menunjukkan kepastian hukum secara berdiri sendiri tanpa digabungkan dengan dalil lain, sebagaimana penjelasan terdahulu. Hal tersebut karena yang demikian itu nampaknya sulit terjadi. (AI-Syâthibi, 2003 :32).

Dalam SK Nomor: 6/MUNAS VII/MUI102005, MUI menetapkan 3 butir tentang kriteria maslahat. Pertama: Maslahat menurut hukum Islam adalah tercapainya tujuan syari'ah (maqâshid alsyari'ah) yang diwujudkan dalam bentuk terpeliharanya lima kebutuhan primer (aldharuriyyât al-khams), yaitu agama, akal, jiwa, harta dam keturunan. Kedua: Maslahat yang dibenarkan oleh syari'ah adalah maslahat yang tidak bertentangan dengan nash. Oleh karena itu, maslahat tidak boleh bertentangan dengan nash. Ketiga: Yang berhak 
menentukan maslahat-tidaknya sesuatu menurut syara' adalah lembaga yang mempunyai kompetensi di bidang syari'ah dan dilakukan melalui ijtihad jama'i.

\section{E. Penutup}

Dari pemaparan di atas dapat disimpulkan bahwa Majelis Ulama Indonesia adalah lembaga yang independen dan aspiratif. Dalam keputusan-keputusan fatwa yang dikeluarkan oleh MUI lebih mempertimbangkan aspek kekuatan dalil dan kemaslahatan umat Islam.

Dalam metodologi pengambilan sebuah hukum, MUI mengikuti alur jumhur (mayoritas) ulama dalam setiap prosesnya. Mulai dari sumber hukum yang disepakati (al-Quran, sunnah, ijmâ' dan qiyas) hingga sumber hukum yang diperdebatkan oleh para ulama klasik, seperti istihsân, istishâb, sad al-dzari'ah dan lain-lain.

Dalam mengeluarkan keputusan fatwa, MUI meletakkan mazhab ulama klasik (Abu Hanifah, Malik, Al-Syâfi'i dan Ahmad) sebagai patokan utama. Jika terdapat perbedaan pendapat MUI mengambil jalan tarjih (menguatkan salah satu pendapat). Akan tetapi MUI tidak mendetailkan metode tarjih yang ditempuh dalam menguatkan salah satu mazhab.
Begitu juga dalam membahas sebuah masalah yang belum dibahas sebelumnya oleh ulama. Metode yang digunakan oleh MUI adalah metode takhrij. Yaitu dengan menganalogikan masalah yang belum dibahas dengan masalah yang sudah dibahas sebelumnya oleh para ulama dengan segala ketentuannya. Jika tidak menemukan kemiripan dalam masalah yang ada, MUI menggunakan metode ijtihad kolektif. Alur pengambilan hukum Islam yang digunakan oleh MUI adalah alur jumhur (mayoritas) ulama.

Majelis Ulama Indonesia juga sangat aspiratif. Aspirasi keagamaan umat Islam ditampung dan dibahas. Sehingga posisi MUI di tengah umat Islam sangat kuat. Dan fatwa yang dilahirkan oleh MUI mendapat dukungan dari umat Islam.

Namun keputusan fatwa MUI bukanlah hukum positif di Indonesia. Walaupun MUI memiliki basis dukungan yang kuat dari umat. Proses pengambilan hukumnya melalui ijtihad kolektif Ulama Indonesia. Semua itu hanya bersifat masukan positif dan aspirasi umat Islam kepada pemerintah. Perlu ada sinergisitas antara pemerintah dan Majelis Ulama Indonesia yang notabene adalah perwakilan dari simpul umat Islam Indonesia. Sehingga kehidupan beragama, berbangsa dan 
bernegara bisa berjalan secara harmonis di Indonesia.

\section{F. Daftar Pustaka}

Al-Aâmidi, Saif al-Din Ali bin Ali bin Muhammad bin Sâlim. Al-Ihkâm fi Ushul al-Ahkâm (Kairo: Maktabah Shubaih, $1387 \mathrm{H}$ ).

Al-'Abbâdi, Syihâb al-Din Ahmad bin Qâsim. Al-Ayât al-Bayyinât ala Syarh Jam'l al-Jawâmi' (Kairo: AlMathba'ah al-Kubra, $1356 \mathrm{H}$ ).

Al-Asfahâni, Abu al-Qâsim al-Husain bin Muhammad. Al-Mufradât fi Gharib al-Qurân (Damaskus: Dâr alQalam, 1412).

Al-Bahsain, Ya'qub bin Abdul Wahab. AlTakhrij 'inda al-Fuqaha' wa alUshuliyyin, Dirâsah Nazhariah Tathbiqiyyah Ta'shiliyyah (Riyadh: Maktabah al-Rusyd, 1414 H).

Al-Ghazâli, Muhammad bin Muhammad. Al-Mustashfâ (Beirut: Dâr al-kutub al-'ilmiyyah, 1993).

Al-Hifnâwi, Muhammad Ibrahim Muhammad. Al-Ta'ârudh Wa alTarjih 'inda al-Ushuliyyin Wa Atsaruhumâ fi al-Fiqh al-Islâmiy (Mansura: Dâr al-Wafâ li alThibâ'ah wa al-Nasyr wa al-Tauzi', 1987).

Al-Isnawi, Abdul Rahim bin al-Hasan bin Ali. Nihâyatu al-Sul Syarh Minhâj
al-Wushul (Beirut: Dâr al-Kutub al'Ilmiyyah, 1999).

Al-Maliki, Muhammad bin Ali bin Husain. Dhawâbith al-Fatwâ (Iskandariah: Dâr al-Furqân, 1998).

Al-Minyawi, Abu al-Mundzir Mahmud bin Muhammad bin Mustafa. Al-Syarh al-Kabir li Mukhtashar al-Ushul (Kairo: Al-Maktabah al-Syamilah, 2011).

Al-Qaradawi, Yusuf. Al-Fatwâ Baina alIndhibath wa al-Tasayyub (Kairo: Dâr al-Shahwah li al-Nasyr, 1988). Al-Qarâfi, Syihab al-Din Ahmad bin Idris. Al-Dzakhiirah (Beirut: Dar al-Gharb al-Islamiy, 1994)

Al-Razi, Fakhru al-Din Muhammad bin Umar al-Husain. Al-Mahshul fi ilmi al-Ushul. (Riyadh: Jâmi'ah al-Imâm Muhammad bin Saud, 1400 H).

Al-Syâfi'i, Muhammad bin Idris. AlRisâlah (Beirut: Dâar al-Kutub al'Ilmiyyah, 1940)

Al-Syaukani, Muhammad bin Ali bin Muhammad bin Abdullah. Irsyâd alFuhul ila tahqiq al-Haq min 'ilm alUshul (Kairo: Dâr al-Kitab al-'Arabi, 1999).

Al-Syâthibi, Abu Ishâq Ibrahim bin Musâ bin Muhammad. Al-Muwâfaqât (Riyadh: Dâr lbn al-Qayyim, 2003). Al-Syirazi, Abu Ishâq bin Ibrahim bin Ali. Al-Luma' fi Ushul al-Figh 
(Damaskus: Dâr al-Kalim alThayyib, 1995).

Azra, Azumardi. Menuju Masyarakat Madani: Gagasan, Fakta dan Tanggapan

(Bandung:

Rosdakarya, 2000).

Ibn Hamdan, Ahmad. Shifat al-Mufti wa al-Mustafti (Beirut: al-Maktab alIslâmiy, 1397H).

Ibrahim, Muhammad Yusri. Al-Fatwâ, Ahammiyatuhâ, Dhawâbithuhâ, Aâtsaruhâ. (Kairo: Dâr al-Yusr, 2007).

Ibn Khaldun, Abdul Rahman bin Muhammad. Al-Muqaddimah Tarikh al-'Allâmah Ibn Khaldun (Madinah: Dâr al-Madinah alMunawwarah, 1984).

Ibn Manzhur, Muhammad bin Makram bin Ali. Lisân al'Arab (Beirut: Dâr al-Shâdir, 1414 H).

Ibn Qayyim, Muhammad bin Abu Bakar Ayyub. I'lâm al-Muwaqqi'in 'an Rabbi al-'Alamin (Beirut: Dâr alJail, 1973)

Ibn Taimiyah, Ahmad bin Abdul Halim, Majmu' al-Fatâwâ (Riyadh: AlRiâsah al-Ammah li al-Iftâ', 1407 H).

Ibn Taimiyah, Abu al-Barakât Abdu alSalâm. Al-Musawwadah fi Ushul alFiqh (Riyadh: Dâr al-Fadhilah, 2001).
Madkuur, Muhammad Salâm. Ushul alFiqh al-Islâmiy (Kairo: Dâr alNahdhah al-'Arabiyah, $1395 \mathrm{H}$ ).

Mudzhar, Muhammad Atho, FatwaFatwa Majelis Ulama Indonesia; Sebuah Studi Tentang Pemikiran Hukum Islam di Indonesia 19751988 (Jakarta: INIS, 1993).

Zein, Satria Effendi M. Problematika Hukum Keluarga Islam Kontemporer: Analisis Yurisprudensi dengan Pendekatan Ushuliyah (Jakarta: Prenada Media, 2005).

20 Tahun Majelis Ulama Indonesia (Jakarta: Sekretariat MUI, 1995).

Firmansyah, Teguh. Republika News, 09 November 2016 "MUI: Pendapat dan Sikap Keagamaan Soal Ahok Lebih Tinggi dari Fatwa" dalam (http://www.republika.co.id/berita/n asional/politik/16/11/09/ogcwxx377 -mui-pendapat-dan-sikapkeagamaan-soal-ahok-lebih-tinggidari-fatwa), diakses pada tanggal 20 Januari 2017.

http://mui.or.id/index.php/category/produ k-mui/ diakses pada tanggal 20 Januari 2017.

Hamdani, Muhammad Ibrahim. DMI berita, 26 Agustus 2015 "Pola Hubungan MUl-Pemerintah Bersifat Simbiosis Mutualisme" dalam (http://dmi.or.id/pola- 
hubungan-mui-pemerintah-bersifat-

simbiosis-mutualisme/) diakses

pada tanggal 19 Januari 2017.

"Kriteria Maslahat" dalam

(http://mui.or.id/wp-content/

uploads/2014/11/40.-Kriteria-

Maslahat.pdf) diakses pada

tanggal 23 Januari 2017.
"Pedoman Penetapan Fatwa Majelis

Ulama Indonesia" dalam

(https://jacksite.files.wordpress.co

m/2007/08/pedoman-penetapan-

fatwa-majelis-ulama-indonesia.pdf)

diakses pada tanggal 19 Januari 2017. 